\title{
Solar radiation absorption according to the tree crown conduction and the effects on peach cultivars production
}

\author{
Evandro Pedro Schneideri*, Edgar Ricardo Schöffel², José Carlos Fachinello²
}

\author{
'Federal University of Fronteira Sul, Cerro Largo, RS, Brazil. \\ ${ }^{2}$ Federal University Pelotas, Pelotas, RS, Brazil. \\ *Corresponding author, e-mail: evandro.schneider@uffs.edu.br
}

\begin{abstract}
In order to reach high productive efficiency, three training systems of the crown in peach trees were evaluated for the efficiency of absorption of solar radiation, aiming to identifying which system of conduction can provide a higher absorption of solar radiation and its effects on the production of the 'Eldorado' and 'Jubileu' peach cultivars. The crown of the trees were conducted in Central Leader, Y-shape and in open Vase systems. Measuring the global solar radiation, reflected solar radiation and the transmitted solar radiation, it was possible to obtain the absorbed solar radiation and the efficiency in radiation absorption by each system of conduction. The 'Jubileu' and 'Eldorado' peach trees were not different for the solar radiation absorption. The Central Leader and open Vase systems present capacity to retain up to $75 \%$ of the solar incident radiation while the Y-shape system retains up to $45 \%$ of the radiation. The peach production in the open Vase system resulted in $36.1 \mathrm{~kg} \mathrm{plant}^{-1}$, higher than $25.47 \mathrm{~kg} \mathrm{plant}^{-1}$ obtained in the Central Leader system, while the production in Y-shape system reached the production of $29.85 \mathrm{~kg} \mathrm{plant}^{-1}$.
\end{abstract}

Keywords: microclimate, plant architecture, pruning, Prunus persica (L.) Batsch, intercepted solar radiation

\section{Introduction}

The fruit production is an activity with an ample possibility of growth in Brazil, due to its capacity to generate employment and income and due to the adequate soil and climate conditions found in different regions of the country. The fruit produced in Brazil is achieving the world market and opening space to transform Brazil into a major exporter, creating new opportunities in agribusiness (Fachinello et al., 2011).

The national production of peaches in 2015 in the country was 216,987 tons in an area of 17,436 hectares and the national average productivity was $12,402 \mathrm{~kg} \mathrm{ha}^{-1}$. The state of Rio Grande do Sul concentrates the highest production of peaches, with 128,924 tons in 12,574 hectares, establishing the average yield of $10,253 \mathrm{~kg} \mathrm{ha}^{-1}$ (lbge, 2015). The municipality of Pelotas concentrates a significant contingent of fruit growers, (about 4,838), responsible for most of this fruit supply for industrial processing in the country (Norenberg \& Ehlert, 2010). The knowledge of crop practices, the market and the climatic conditions of the Rio Grande do Sul state favor the growth of the fruit activity in this region. However, the peach produced in the southern region of Brazil, although of great flavor, often do not achieve the size, appearance and firmness desired by international standards (Wagner Junior et al., 2011; Gonçalves et al., 2014). Thus, orchard 
and plant management practices are important to reach these quality attributes (Gonçalves et al., 2014).

In order to promote the best utilization of the productive area and the anticipation of the return of the invested capital, the fruit growers tend to implant more compact orchards and adopt different management systems for the crop. Studies regarding pruning (Trevisan et al., 2006, Rodrigues et al., 2009; Galarça et al., 2013; Gonçalves et al., 2014) and orchards spacing (Giacobbo et al., 2003; Mathias et al., 2008; Mayer \& Pereira, 2011) were developed, but all with limitations on the evaluation of the interception of solar radiation, since the evaluated characteristics were fruit production, color and quality.

The complete auto shading of the lower part of the crown is not interesting for the peach tree, as in most perennial crops, despite the photochromic adaptations of the shaded leaves, the peach tree can reduce the number of internal branches of production (Tomaz et al., 2010). Thus, most of the internal scion organs become dependent on photosynthesized compounds from the outermost parts of the plant (Magalhães, 1979).

For Vitti (2003) the solar radiation intercepted by the fruit tree crown establishes the area's yield potential, suggesting that high yields are obtained with the conduction system that provides greater absorption of the solar radiation.

The knowledge about interception and absorption patterns of solar radiation can guide cultivar selection projects, as well as assist in the selection of efficient vegetative canopy management and even invasive weeds management (Caron et al., 2012). The photosynthetic efficiency of a canopy is affected by the photosynthetic rate per unit of leaf area, because absorption of the intercepted radiation alters the radiation and energy balance, and depends on the architecture and dimension of the tree crown (Gallo et al., 1993; Cunha \& Volpe, 2010). According to Trevisan et al. (2006), the homogeneous distribution of solar radiation influences characteristics such as color of epidermis, size and sugar concentration in peach fruits. In addition, studies involving crop irrigation consider the need for specific management to the different conditions of fruit cultivation. Auzmendi et al. (2011) indicates the measurement of intercepted solar radiation as the main factor to aid in the irrigation quantification.

In order to obtain a high productive efficiency of peach trees, three systems of plant crown conduction (Central Leader, Y-shape and Vase) were compared regarding the efficiency of absorption of solar radiation in order to identify the system of conduction that provides greater absorption of solar radiation and its effects on the production of the 'Eldorado' and 'Jubileu' cultivars.

\section{Material and Methods}

The research was installed in the peach orchard of the Agricultural Center of Palma $\left(31^{\circ} 52\right.$ 'S and $\left.52^{\circ} 21^{\prime} \mathrm{W}\right)$, at the Federal University of Pelotas, located in the municipality of Capão do Leão, RS, Brazil. The treatments consisted of two peach cultivars and three crown conduction systems. The 'Eldorado' and 'Jubileu' peach cultivars were grafted on the Capdebosca rootstock and planted in the year 2000, being conducted in the Central Leader (LC), Y-shape $(Y)$ and Vase (V) systems under the same planting density, spaced $1.5 \mathrm{~m}$ between plants and $5.5 \mathrm{~m}$ between rows, arranged in a northsouth direction. In winter pruning, the plants were standardized for height for each driving system (Central Leader up to $3.5 \mathrm{~m}$, Vase and Y-shape up to $2.5 \mathrm{~m}$ ) and pruned in winter to maintain up to 200 productive branches per plant.

In order to evaluate the incident solar radiation, reflected and transmitted by the crop canopy, fixed timber structures built to support the installation of radiometers were placed in the planting line of each treatment. The radiometers used were solarimeters tubes type, made of printed circuit boards, similar to those used by Duarte et al. (2010).

In each treatment two radiometers were installed above the plant, one of them positioned with the sensor facing upwards, measuring the incident solar radiation (global solar radiation, $\mathrm{Sr}$ ) and another installed with the sensor facing downwards, measuring the reflected radiation 
(Rr) by the crop in the central portion of each conduction system (Figure 1). In addition, a third solarimeter tube was placed at $0.20 \mathrm{~m}$ above the ground to measure the transmitted radiation (Tr) through the vegetative canopy. From January through to late May 2010, the sensors remained connected to a Campbell Scientific ${ }^{\circledR}$ data acquisition system, model CR 21X, which processed the sensor readings on every thirty seconds, and stored the mean values on every

\section{0 minutes.}

In order to compare the solar radiation absorption values in each of the peach trees, two typical days with low cloudiness were selected. Data from a heliograph installed at the Pelotas Agroclimatic Station were used, approximately $2.5 \mathrm{~km}$ from the experimental area. On the selected days, treatments were compared at each time of sun exposure.
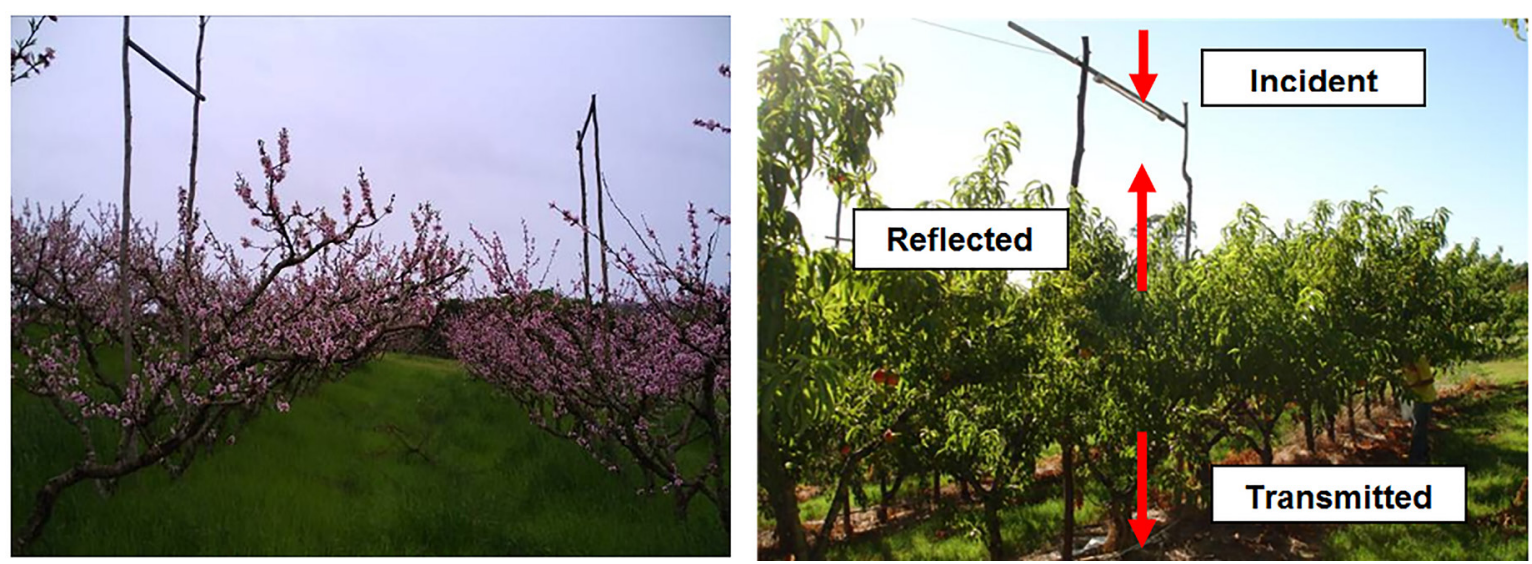

Figure 1. Structure for the evaluation of the incident, transmitted and reflected solar radiation by the peach tree. Pelotas-Rs, Brazil, 2015.

The absorbed solar radiation $\left(R_{a b s}\right)$ by the peach tree was estimated through the equation:

$$
\mathrm{R}_{\mathrm{abs}}=\mathrm{Rs}-\mathrm{Rr}-\mathrm{R} \dagger
$$

Rs- global solar radiation (or incident solar radiation); Rr- reflected solar radiation by the plant; Rt solar radiation transmited by the plant.

The efficiency of the solar radiation $\left(\varepsilon_{\mathrm{abs}}\right)$ absorption was estimated by:

$$
\varepsilon_{\mathrm{abs}}=\mathrm{R}_{\mathrm{abs}} \mathrm{Rs}^{-1}
$$

The experiment was carried out in a randomized block design, according to the $2 \times 3$ factorial, with two cultivars ('Eldorado' and 'Jubileu') and three systems of the crown conduction (Central Leader, Y-shape and Vase), with three repetitions. Each experimental unit was composed of 15 plants. In order to obtain the phenometric (fruit number and fruit diameter) and production data, the fruits of four plants of each experimental unit were harvested. The significant variables by $F^{\prime}$ 's test $(P \leq 0.05)$ had the means compared by the Tukey's test at 5\% of error probability, using WinStat - Statistical Analysis System for Windows - version 2.0 statistical software.

\section{Results and Discussion}

The variance analysis for the variable absorbed solar radiation did not demonstrate a significant effect of the triple interaction between the factors (cultivar $x$ conduction system $x$ exposure time), but there was a significant effect of interaction between the factors exposure time and conduction system.

As can be seen in Figure 2a, for a clear day (April 15), there was a progressive increase (9am to 12) in absorbed solar radiation (Rabs) by the peach tree using the Central Leading (LC) conduction system, This was the period with the highest incidence of solar radiation ( $\mathrm{Rs}=680$ $\mathrm{W} \mathrm{m}^{-2}$ ), reaching an average of $590 \mathrm{~W} \mathrm{~m}^{-2}$. The Vase (V) system of conduction presented the same tendency to increase solar radiation up to 11:00am (420 $\mathrm{W} \mathrm{m}^{-2}$ ), differing from the Central Leader system only for the period of 11:00am to 12:00, when presented $30 \%$ less absorption. 
For the Y-shape system, the increase in radiation absorption occurred up to 11:00 am $\left(515 \mathrm{~W} \mathrm{~m}^{-2}\right)$, with a sharp fall from this time to only $120 \mathrm{~W} \mathrm{~m}^{-2}$ in the period from 11:00 am to 12:00h, remaining with means below the other training systems until 1:00pm. From this moment, the Y-shape presented similar than other system with a moderate decrease at the end of the day (Figure 2a). From 9:00am to 11:00am, the conduction systems did not statistically modified the absorption of radiation.
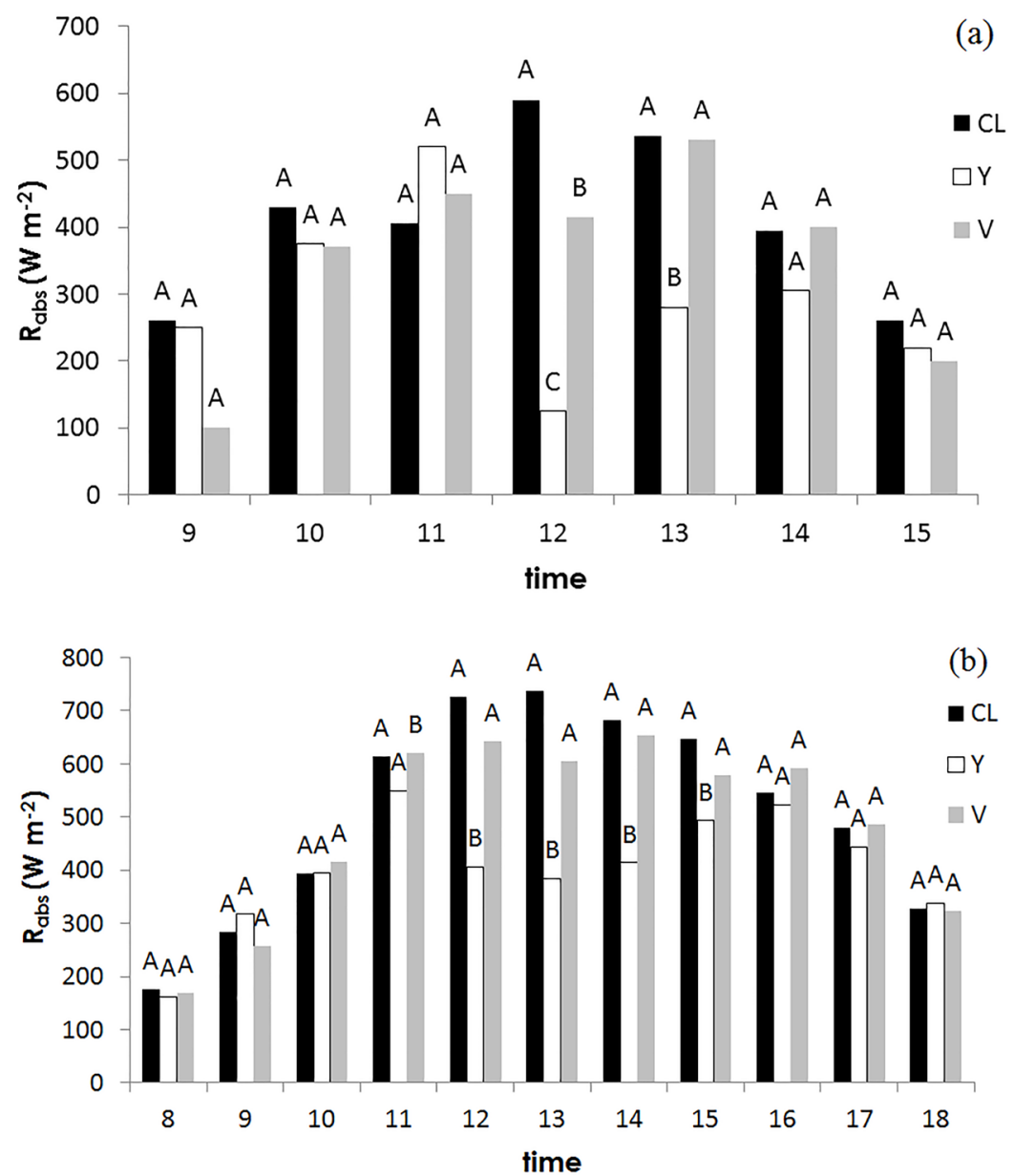

Figure 2. Solar radiation absorbed by the peach crown using the conductions in central leader (CL), Y-shape (Y) and vase (V) during April $15^{\text {th }}(\mathrm{a})$ and January $15^{\text {th }}$. Means followed by the same uppercase letter at the same hour are not statistically different according to Tukey's test ( $\mathrm{p} \leq 0.05)$.

The conduction in vase resulted in values close to those observed in the Central Leader system, due to the formation of the crown filled by leaves, since it has main branches in different directions, making the center of the crown covered by leaves. The Y-shape system of conduction presented a lower leaf density in the center of the vegetative canopy. This characteristic of keeping only two branches in opposite positions lead to higher incident radiation on the middle of the tree, which is transmitted through the vegetative canopy, resulting in lower values of absorbed radiation during the period of higher solar elevation.
When the plants were in the floral differentiation stage of the buds (January), the measurements of solar radiation absorbed by the Central Leader and Vase systems did not differ significantly during the day, but the Y-shape system resulted in lower values from 12:00 to 3:00pm, for example, for a day with no clouds (January 15, Figure 2b). These values were similar to $400 \mathrm{~W} \mathrm{~m}^{-2}$ in the period in which the other systems resulted in values higher than $600 \mathrm{~W} \mathrm{~m}^{-2}$. This corroborates with results obtained by Reisser et al. (2007), who also observed differences in the interception of radiation during the day for the peach tree, where the systems with the center of 
the crown filled presented greater interception in the period of greater incidence of the radiation. It can be noticed that after 1:00pm in April (Figure 2a) and at 3:00pm in January (Figure $2 \mathrm{~b})$, the conduction systems did not resulted in significant statistical differences. This equivalence is probably a consequence of the topography of the experiment site, where the exposure of the terrain provides shorter sunshine during the afternoon, especially at times of the year distant from the summer solstice.

It can be seen that the crown architecture was a determinant factor in the absorption of solar radiation, where the Central Leader system, due to the main characteristic of maintaining a central axis, presents greater absorption of the incident solar radiation when compared to the Vase and Y-shape forms, at periods when the sun, in its apparent movement, approaches the local meridian, that is, when the angle of solar elevation approaches $90^{\circ}$. Because of its central axis partially filled by branches, the Vase system resulted in similar values than the Central Leader and different from the Y-shape system, which presents few branches in the central part of the plant (Figure 2a, b). According to Vitti (2003), the interception of radiation decreases from the Central Leader system to the Y-shape and Vase systems, which confirms the values found for the first, but differs for the comparison among Y-shape and vase. However, Vitti (2003) did not standardize the plants for the number of productive branches, which may justify the observed difference.

According to the analysis of variance, it was not observed an effect of the cultivar, only effect of the simple interaction between the exposure time and crown shape on the efficiency of solar radiation absorption ( $\varepsilon a b s$ ). Comparing the crown shape for $\varepsilon a b s$ (Figure 3), it is possible to identify that the Central Leader and the Vase have the capacity to retain in the vegetative canopy up to $75 \%$ of the incident solar radiation, surpassing the Y-shape system, that in the period from 11:00 am to noon and 1:00pm to 2:00pm, respectively, retained 25 and $45 \%$ of the radiation, being the exceeding solar radiation transmitted through the canopy to the soil or reflected by the plant to the atmosphere.
The variation in the cabs at the different periods of the day (Figure 3 ) is mainly due to the low capacity of interception of radiation in the Y-shape system in the period of highest incidence of radiation, from 11:00 am to 12:00. In this period, the solar inclination is lower and the solar radiation reaches the center of the canopy, which presented few leaves. These results confirm those obtained by Reisser et al. (2007), who verified that crown of trees that with the center filled have a smaller variation in the interception efficiency in the period of higher radiation incidence.

The cultivar 'Jubileu' presented fruits with higher fresh mass when compared to the 'Eldorado' cultivar using the three systems of conduction (Table 1). The fruit fresh mass was not different with the use of the conduction systems the 'Eldorado' cultivar. However, for the 'Jubileu' the Y-shape system of conduction resulted in higher values (Table 1). Evaluating the effect of the conduction system on the production per plant and the average mass of the pears fruits, during six years, Petri et al. (2008) did not identify interference of the conduction system on the fruits of that species.

Comparing cultivars for fruit diameter, 'Jubileu' presented higher values than 'Eldorado! Using the Y-shape and Vase, but did not differ when the Central Leader system was used (Table 1). The fruit diameter of the Jubileu cultivar was higher in the plants conducted in the Y-shape system than in the Central Leader and Vase systems, while for the 'Eldorado' cultivar the conduction system did not affected the fruit diameter. This is in agreement with results obtained by Caruso et al. (1998), who, when comparing the systems Leading Central and Y-shape in peach trees, concluded that the second presented bigger fruits and of better quality.

In the evaluation of the number of fruits and productivity, only a simple interaction was observed for the conduction system factor. Therefore, the data of the cultivars 'Jubileu' and 'Eldorado' were grouped, obtaining an average per conduction system. Thus, the Vase conduction system stands out for the production per plant, presenting a higher number of fruits 
and fruit production per plant than the Central Leader system, not statistically different from Y-shape (Table 2).

The higher absorption of solar radiation by the Central Leader system compared to the Y-shape system (Figures 2 and 3 ) did not provide an advantage to obtain a greater number of fruits and production per plant, demonstrating that, despite the greater interception of radiant energy, the Central Leader system may be less effective for the transmission of this energy into the canopy.

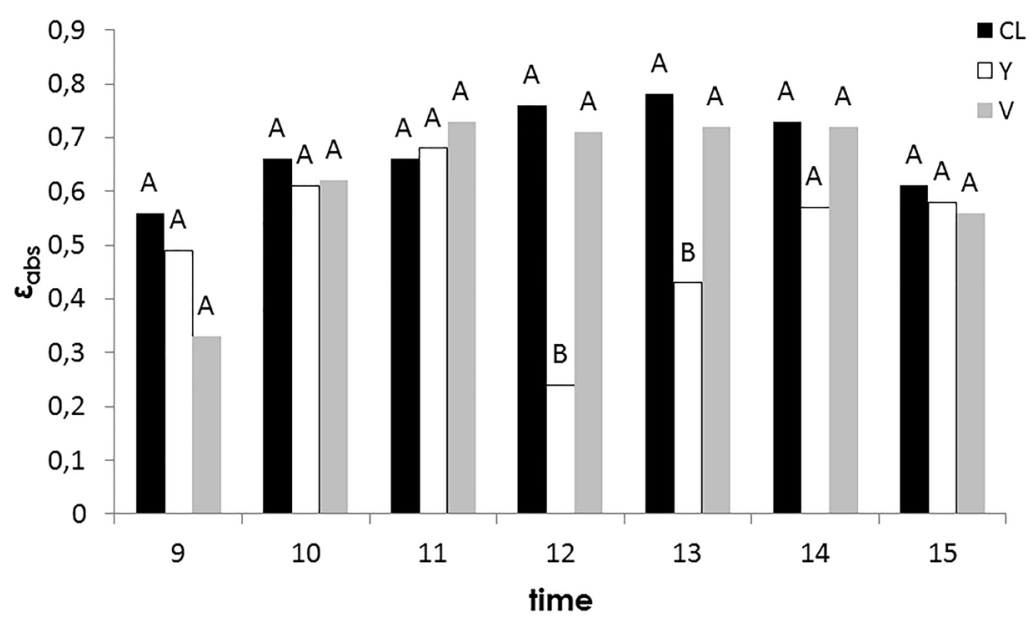

Figure 3. Efficiency of absorption of the incident radiation $\left(\varepsilon, \varepsilon_{\text {abs }}\right)$, in peach plants with crown conducted in central leader (CL), Y-shaoe (Y) and vase (V). FAEM/UFPel, Pelotas-RS, Brazil, 2015. Means followed by the same uppercase letter at the same hour are not statistically different according to Tukey's test.

Table 1. Fresh mass and fruit diameter from 'Jubileu' and 'Eldorado' peach trees according to the crown conduction. Pelotas-RS, Brazil, 2015.

\begin{tabular}{lllll}
\hline & \multicolumn{2}{l}{ Fruit fresh mass $(\mathrm{g})$ per cultivar } & \multicolumn{2}{l}{ Fruit diameter $(\mathrm{mm})$ per cultivar } \\
\cline { 2 - 5 } Crown conduction & Eldorado & Jubileu & Eldorado & Jubileu \\
\hline Central Leader & $131.01 \mathrm{Ba}^{*}$ & $141.77 \mathrm{Ab}$ & $62.98 \mathrm{Aa}$ & $63.27 \mathrm{Ab}$ \\
Y-shape & $133.78 \mathrm{Ba}$ & $161.64 \mathrm{Aa}$ & $63.24 \mathrm{Ba}$ & $67.35 \mathrm{Aa}$ \\
Vase & $130.52 \mathrm{Ba}$ & $141.47 \mathrm{Ab}$ & $61.79 \mathrm{Ba}$ & $64.17 \mathrm{Ab}$ \\
\hline $\mathrm{CV}(\%)$ & 8.1 & \multicolumn{4}{l}{2.8} & \\
\hline${ }^{*}$ For each variable, means followed by the same uppercase letter in the line and lowercase in column are not statistically different
\end{tabular}

according to Tukey's test ( $p \leq 0.05$ ); CV: coefficient of variation.

Table 2. Means for the number and production of peach fruits per plant using three systems of crown management. Pelotas-RS, 2015.

\begin{tabular}{lccc}
\hline \multicolumn{4}{c}{ Crown conduction } \\
\cline { 2 - 4 } & Central Leader & Y-shape & Vase \\
\hline Number of fruits & $187.88 \mathrm{~B}$ & $213.27 \mathrm{AB}$ & $264.73 \mathrm{~A}$ \\
Fruit production $(\mathrm{kg})$ & $25.47 \mathrm{~B}$ & $29.85 \mathrm{AB}$ & $36.10 \mathrm{~A}$ \\
\hline${ }^{*}$ Means followed by the same uppercase letter in the line are not statistically different according to Tukey's test $(\mathrm{p} \leq 0.05)$;
\end{tabular}

In addition, less vigorous plants have a better distribution of the solar radiation inside the crown, which increases the differentiation of flowering buds. For example, in shaded apple trees, with $30 \%$ less light penetration, there is practically no development of flowering buds (Tomaz et al., 2010).

However, the results obtained in canopy plants conducted in the Vase system indicate that this plant architecture was efficient in the interception of solar radiation and also in the use of solar energy for production. These results differ from those obtained by Giacobbo et al. (2003), who, studying the same systems of conduction, observed higher productivity in the Central Leader system, however, those authors studied different planting densities for each system, being difficult the representation of the production by area. 


\section{Conclusions}

Peach cultivars 'Jubileu' and 'Eldorado' have the same efficiency in absorbing solar radiation. The system of conduction of the peach tree influences the absorption of solar radiation. At higher solar elevation times, peach plants with crowns conducted in Central Leader and Vase shapes presented higher absorption of solar radiation than the Y-shape crown. The Vase system presents greater productive efficiency.

\section{References}

Auzmendi, M.M., Lopez, G., Girona, J., Marsal, J. 2011. Intercepted radiation by apple canopy can be used as a basis for irrigation scheduling. Agricultural Water Management 98: 886-892.

Caron, B.O., Souza, V.Q., Costa, E.C., Eloy, E., Behling, A, Trevisan, R. 2012. Interceptação da radiação luminosa pelo dossel de espécies florestais e sua relação com o manejo das plantas daninhas. Ciência Rural 42: 75-82.

Cunha, A.R., Volpe, C.A. 2010. Relações radiométricas no terço superior da copa de cafeeiro. Bragantia 69: 263 - 271.

Duarte, G.B., Schöffel, E. R., Mendez, M.E.G., Paula, V.A. 2010. Medida e estimativa da evapotranspiração do tomateiro cultivado sob adubação orgânica em ambiente protegido. Semina: Ciências Agrárias 31: 563-574.

Fachinello, J.C., Pasa, M.D.S., Schmtiz, J.D., Betemps, D.L. 2011 . Situação e perspectivas da fruticultura de clima temperado no Brasil. Revista Brasileira de Fruticultura 33: 109-120.

Gonçalves, M.A., Cocco, C., Vignolo, G.K., Picolotto, L., Antunes, L.E.C. 2014. Efeito da intensidade de poda na produção e qualidade de frutos de pessegueiro. Revista Brasileira de Fruticultura 36: 742-747.

IBGE. Instituto Brasileiro de Geografia e Estatística. Produção Agrícola Municipal. In: Associação Brasileira de Estudos Urbanos e Regionais, 2015. http://www.ibge.gov.br/home/estatistica/ economia/pam/2015/default_xls.shtm. consulta: Novembro de 2015.

Galarça, S.P., Fachinello, J.C., Betemps, D.L., Hoffmann, A., Marodin, G.A.B., Pretto, A., Nunes, F.S., Dias, F.P. 2013. Crescimento e desenvolvimento de pessegueiros 'Chimarrita' e 'Maciel' sobre diferentes porta-enxertos e locais de cultivo. Ciência Rural43: 219-224.

Giacobbo, C.L., Faria, J.L.C., Conto, O.D., Barcellos, R.F.D., Gomes, F.R.C. 2003. Comportamento do pessegueiro (Prunus pérsica
L. Batsch) cv. Chimarrita em diferentes sistemas de condução. Revista Brasileira de Fruticultura 25: $242-244$.

Mathias, C., Mayer, N.A., Mattiuz, B., Pereira, F.M. 2008. Efeito de porta-enxertos e espaçamentos entre plantas na qualidade de pêssegos 'Aurora-1'. Revista Brasileira de Fruticultura30: 165170.

Mayer, N.A., Pereira, F.M. 2011. Produtividade de pessegueiros 'Aurora-1' em diferentes espaçamentos e métodos de propagação do porta-enxerto 'Okinawa. Bragantia 71: 372-376.

Norenberg, E.M, Ehlert, E. 2010. Análise e Tendências Futuras para o Pêssego na Região de Pelotas no Contexto Globalizado.VIII Encontro Nacional da Associação de Estudos Regionais e Urbanos, Juiz de Fora: Associação Brasileira de Estudos Regionais e Urbanos. 270p. http://www. estudosregionais.org.br/admin/upload/File/ A270.doc consulta: Setembro de 2015.

Reisser, C.J., Pereira, J.F.M.,Steinmetz, S.,Herter, F.G.,Wrege, M.S., Gonçalves, R.S., Louzada, R.S.,Costa, A.V.2007. Avaliação da eficiência da interceptação da radiação solar em diferentes sistemas de condução de pessegueiro. XV Congresso Brasileiro de Agrometeorologia. Aracaju: Sociedade Brasileira de Agrometeorologia. 540p. CD-ROM

Rodrigues, A., Araujo, J.P.C., Girardi, E.A., Scarpare Filho, J.A. 2009. Desenvolvimento do pessegueiro 'Flordaprince' sob duas intensidades de poda verde. Bragantia 68: 673-679.

Tomaz, Z.F.P., Lima, C.S.M., Gonçalves, M.A., Rufato, L., Rufato, A.R. 2010. Crescimento vegetativo, floração e frutificação efetiva do pessegueiro 'Jubileu' submetido a diferentes comprimentos de interenxertos. Pesquisa Agropecuária Brasileira 45: 973-979.

Trevisan, R., Gonçalves, E. D.,Chavarria G., Antunes, L. E. C.,Herter, F. G. 2006. Influência de práticas culturais na melhoria da qualidade de pêssegos. Revista Brasileira de Agrociência 12: $491-494$.

Vitti, M.R. 2003. Interceptação da radiação solar por plantas de pessegueiro (Prunuspersica L. Batsch) Cv. chimarrita em diferentes sistemas de condução e sua relação com características físicas e químicas das frutas. Dissertação de Mestrado em Agronomia. Faculdade de Agronomia Eliseu Maciel, Universidade Federal de Pelotas, Pelotas. 59p. https://books.google. com.br/books?id=mPNjkgEACAAJ consulta: Setembro de 2015

Wagner Júnior, A.,Bruckner, C.H.,Cantín, C.M., Sánchez, M.A.M.,Cruz, C.D.2011. Divergências 
genéticas entre progênies de pessegueiro em Zaragoza, Espanha. Revista Brasileira de Fruticultura 33: 303 - 310. 